\title{
DESIGN AS AN ELEMENT OF THE SERVICE COMPANY'S STRATEGY
}

\author{
MONIKA TOMCZYK, ${ }^{1}$ MONIKA SPYCHALSKA-WOJTKIEWICZ2
}

University of Szczecin, Faculty of Management and Economics of Services, POLAND

${ }_{1}$ e-mail: monika.tomczyk@wzieu.pl

2 e-mail: monika.wojtkiewicz@wzieu.pl

RECEIVED

ACCEPTED

JEL

CLASSIFICATION

KEYWORDS

ABSTRACT
10 December 2018

28 December 2018

D40, M20, M29, O22, 031

design, design management, service enterprises, innovation, SME sector

As the research conducted by Design Council in UK shows for every $£ 1$ invested in design, businesses can expect over $£ 20$ in increased revenues (Design Council, 2018). This article raises the question whether it is justified to include design in a service company's strategy, and companies' readiness to treat design as a key element of their strategy. The goal of the article is to describe the external and internal conditions that must exist for service companies to incorporate design into their strategies and use it as a generator of value for them. To verify the above issues the desk research analysis and answers from experts gathered during individual in depth interviews has been used. In the course of conducting interviews, it could be noted that despite the fact that experts come from different countries, as well as worked for various entities, they have very convergent views on the entities problems in the implementation of design, as well as on creative innovation management. Experts also had similar guidance for these organizations.

\section{Introduction}

For most of the history design has been treated as the next step in the process of designing objects. R. Loewy designed trains, F. Lloyd Wright houses, C. Chanel haute couture clothes, P. Rand logotypes, while D. Kelley products, including the most famous mouse for the Apple computer. As it became clear that effective design was the foundation of commercial success, companies began to make increasing use of it, and by the 
second half of the twentieth century design had become an increasingly valuable competitive advantage. Today, in order to create a value chain, businesses need to generate ideas that are better suited to the needs and desires of consumers. Thus, for example, high-tech companies that had previously hired designers to invent the shape and layout of smartphones began to ask them to create the appearance of the user interface, then to design the user experience, and then immediately began to use the design process to create a corporate strategy. Nowadays, design is also used to improve the functioning of the stakeholder network and the organization as a system (Brown, Martin, 2015). Design has never been more valued as an economic force, nor has it been as culturally influential as it is now. All types of organizations have begun to adopt "design thinking" (Brown, 2018; Stickdorn, Scheider, 2014, pp. 9-14) as their guiding principle and are building their internal design competencies (Rousseau, 2018).

\section{Design in companies - place and role}

There are many approaches to position of design in companies as well as correlation between design and economic success. One of them suggests that in order to measure and communicate the value of design management, the Balanced Score Card model should be used and be structured in the following four categories (Mozota, 2006):

1. Internal business processes: design management as an innovation process, providing improvements in company performance and processes. Here, these innovations and processes are totally invisible to outsiders.

2. Learning and growing: beyond advanced design management. Design explicit knowledge is applied to strategic focus and improves the quality of staff.

3. Customer and brand: design management as perception and brand. Design knowledge is applied to corporate difference building and strategic positioning.

4. Financial: the historic design management economic model. Design management as an explicit and measurable value for company reputation and stock market performance.

The Danish Design Centre has developed a design ladder to illustrate the use of design by companies. This is a communication model that illustrates the diversity of use of design in organisations. The design ladder is based on the assumption that there is a positive relationship between higher revenues and a greater emphasis on design in the early stages of product or service development, and giving design a more strategic position in the company's overall business strategy. Design can be used at different intensities:

Stage 1: design - not designed:

Design is an invisible part of e.g. product development and is not realized by trained designers. The solutions are based on the ideas of the employees involved in the process and concern good functioning and aesthetics. The user perspective plays little or no role in this process.

Stage 2: design as shaping:

Design is seen only as the final stage of shaping, both in terms of product development and graphic design. Many designers use the term 'styling' in this process. The task can be done by professional designers, but is usually handled by people with a different education.

Stage 3: design as a technological process:

Design is not a result, but an integrated approach at an early stage of the development process. The solution is problem-based and user-driven and requires the involvement of a wide range 
of skills and capabilities, for example, process engineers, materials engineers, marketing experts and administrative staff.

Phase 4: design as a strategy:

The designer works with the owner/management to reconsider the business concept in whole or in part. In this case, the main focus is on the design process in relation to the company's business vision and desired business areas and its future role in the value chain (Design Council, 2018).

\section{How to manage design in a company}

Companies face different challenges when it comes to innovating based on what markets they are in and where they are in terms of growth. Start-ups have a very different set of issues to companies that are expanding rapidly or are operating globally. The processes and systems for capturing, developing and implementing new ideas change. But ultimately all companies face the issue of accelerated change happening in the world, so everyone needs to consider how to be creative and deal with uncertainty. That is why implementing design in service companies can be so important. Nevertheless it is not easy to manage design in company especially when mangers are implanting design for the first time.

The group of experts who took part in the IDI (individual in-depth interviews) study within the scope of the subject analyzed the application of design management rules in the entities they represent or cooperate with. The object of the study was management techniques used in companies and ways of implementation design. For this reason, the technique of qualitative research was chosen to deepen this complex issue. The interviews were conducted in the third quarter of 2018 by the authors (researchers from the University of Szczecin). The results are worth attention because authors managed to obtain information from international eceprts (from Netherlands, Ireland and Germany), who are practitioners of design implementation in entities from various sectors. In the course of conducting interviews, it could be noted that despite the fact that experts come from different countries, as well as worked for various entities, they have very convergent views on the entities problems in the implementation of design, as well as on creative innovation management.

Implementation of user-cantered approach is very often pointed as a way of starting process of design implementation. But also this way of thinking is something that companies still missing. Experts asked in the IDI study what they think about user cantered approach to deliver sustainable innovation, is it common in companies or this is something that companies still have to learn that the very often companies make assumptions about knowing their users, so they may think they are user-cantered, but may not actually spend time with users regularly. Running and growing a business involves a whole range of considerations. Teams can become drawn into meeting short-term tasks and too many meetings inside the company, or become focused on improving their products and services rather than the user experience. It becomes easy to get disconnected with users, or meeting with users can been seen as only for sales people.

According to experts spending time with users is the best way to show people how valuable it can be. So, this is the way to encourage managers to implement user-cantered approach, so that they do not think it is a waste of time or money. Spending time with users reveals a different perspective and often unexpected insights. It is not difficult for people to know that a great user experience is what they want to deliver, the difficulty is structuring ways to do new research on that - with how many people, which people, what type of research? The cost implications are important, so starting with a small sample can be a good way to start. 
The key methodology for effective user research it is work with researchers who capture results in ways that can show clear and compelling insights. The hardest part for companies doing research themselves is that they are biased and can want to hear or see only positive responses. Users can also want to please people if they know the company is theirs, so this makes the problem of open listening and observation harder. According to experts it is essential in any methodology to know what managers are seeking to understand and then how they can create an open situation where people are free to demonstrate or explain their perspective.

In process from research to insight to solution creation experts stated that it is very important to firstly decide on a group of users that is a good representative of users - perhaps typical, or extreme or one particular sub-type. Then there are a range of options in terms of in-context interviews, observation visits, shadowing or immersion. Capturing these visually, verbally and in writing. Then patterns might emerge or something unusual may stand out. These can then be taken back and used to develop prototype solutions for testing. All these stages can be adapted to different scales and budgets depending on what a company wants to achieve.

In process of using design in company it is very important to implement insights and transform them in to a vision statement. To do that managers have to reframe insights into something that can be turned into creative ideas. So rather than 'let's design a better product', insights might reveal a situation where managers can reframe the problem into something more specific such as "new younger customers need a better way to fit our product into small cars, because this is causing them inconvenience and extra cost".

According to experts point of view method that can be recommend to companies for concept building and validation it is to design a way to test an idea in terms of 'minimal viable product'. That might mean taking a prototype to a test group. It might mean a test launch in one region or one store. It might mean also taking a new idea to a trade show for feedback. Whatever way is possible, managers have to turn an idea into something that can be bought or used, so that there is genuine feedback. Asking people 'would you like this' is not strong enough, but a full launch can be too risky. Managers should start small, test early, then iterate - this can be done in the market with user involvement.

Risk management according to experts is very important in commercialization process and still not used by managers very often. Steps that can help in risk management are:

- make checkpoints,

- revisit the original brief,

- be honest about feedback and results,

- keep check on the levels of investment.

According to experts it is also significant that there are examples of innovations that were pushed through with passion even though feedback was negative, but there are many more start-ups that refuse to acknowledge that the idea is not getting good feedback. Knowing when to stop or when to keep going can be a very difficult decision.

Dealing with design and innovation after deployment is also very important because launching is just the beginning even for design issues. Then a business faces a whole new set of sales and distribution issues. According to IDI experts designers or innovators are not always the best people to run and then scale a business, so it is important to have a balanced team with different skills. Launching a new product or service can also involve branding, marketing materials, websites, packaging, interior spaces and any number of other 'touchpoints' in the sales experience. Different designers may be required and budgets need to be prioritized and allocated. A design management role here ensures the full perspective to achieve a strategic goal. 
Experts stressed that still managers have to be encourage to implement design, because they are afraid of the process as well as the costs. So to make it easier there has to be a business case for using design and a clear set of goals in terms of what success will look like and will be measured on. In other words a clear strategic brief needs to be created at the beginning. Too many businesses bring in designers at the end of a project to add a few 'nice looking marketing materials' - and too many designers will also deliver on that basis. It severely limits success and keeps design as 'finishing touches' rather than at the core of the business. When businesses meet and work with designers that have strategic ability, and can demonstrate the benefits and the process, it can change people's perspectives.

\section{Conclusions}

The inclusion of design in a strategy aims to combine business and creative assumptions in a way that goes beyond aesthetic design activities and raises the concept of design to the level of a strategic tool that companies can use. Business and design strategies, although inextricably linked, meet different needs. The first includes financial, product and market objectives, which are best expressed through the points of contact with the brand. The design strategy, on the other hand, is an action plan to implement the visual and media elements that contribute to the achievement of these objectives. The design strategy can be presented as the development of the language that best reflects the business strategy (Koval, 2018).

The design strategy is formulated on the basis of parameters and potential of a specific challenge, which is the driving force for a whole range of solutions. It is simple, convincing and efficient. As with any language, evolution and changeability are inevitable and should be taken into account. It is worth noting that this is in line with the following change in the management and abandonment of know-how, in favour of know-what, which in turn is heading towards know-why. Design focuses on the last phase by guessing consumer expectations, which is only possible through close cooperation between the two parties, starting from the product development phase. In this case, we can speak of an advanced process, based on design (Celaschi, Celi, Garcia, 2011, p. 6).

\section{Referencees}

Brown, T., Martin, R.L. (2015). Design for action. Harvard Business Review, IX, 56-64.

Brown, T. (2018). Our Approach: Design Thinking, IDEO. Retrieved from: www.ideo.com/ about.

Celaschi, F., Celi, M., Garcia, L.M. (2011). Design: An Advanced Design Perspective. Design Management Journal, 6 (1), 6-15.

Design Council (2018). Design for public good. Retrieved from: https://www.designcouncil.org.uk/sites/default/files/asset/document/ Design\%20for\%20Public\%20Good.pdf.

Koval, J. (2018). Performance is the result of designing perfectly to an intention. VSA Partners. Retrieved from: https://www.vsapartners. com/news.

Mozota, B. (2006). A theoretical model for Design in Management science according to the paradigm shift of the Design profession: from management as a constraint to management science as an opportunity. 1st International Design Management Symposium D2B. March 16-19, Shanghai Jiao Tong University.

Rousseau, J. (2018). The Case for Design Consulting, Artefact. Retrieved from: https://www.artefactgroup.com/content/the-casefor-design-consulting.

Stickdorn, M, Schneider, J. (2014). This is service design thinking. Amsterdam: BIS Publisher.

Cite this article as: Tomczyk, M., Spychalska-Wojtkiewicz, M. (2018). Design as an element of the service company's strategy. European Journal of Service Management, 4 (28/2), 499-503. DOI: 10.18276/ejsm.2018.28/2-60. 